\section{Vellykket DUDS Efterårsmøde 2015.}

Tak til Lars Bolvig og Aarhus Universitets Hospital for et velbesøgt og veltilrettelagt Efterårsmøde i Århus den 23. oktober 2015.

Programmet var alsidigt og spændende. Både med eksempler på de mange kliniske anvendelsesmuligheder for ultralydskanning og med fokus på anvendelse af ultralydskanning i symbiose med nye teknologier.

Efter Lars havde budt os velkommen holdt rheumatolog og idrætsmediciner Thøger Persson (Team Danmark/Silkeborg Sygehus) et velillustreret foredrag om frakturdiagnostik med ultralyd. Ultralyd kan vise diskrete ossøse forandringer, der kan repræsentere brud som overses ved traditionel røntgen undersøgelse.

Efterfølgende kom overlæge, dr.med. Søren Rafaelsen (Vejle Sygehus) på podiet og

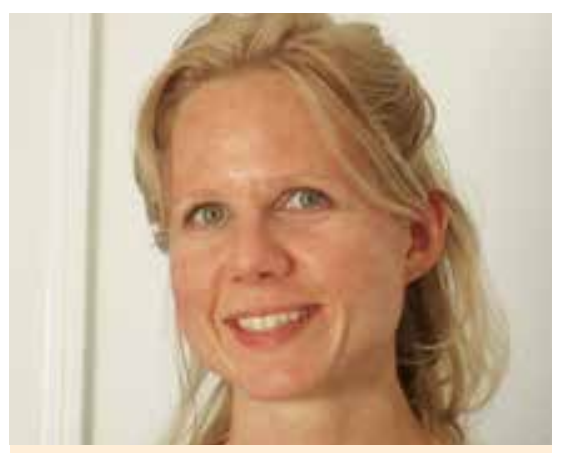

Afd Læge, Ph.D. Caroline Ewertsen

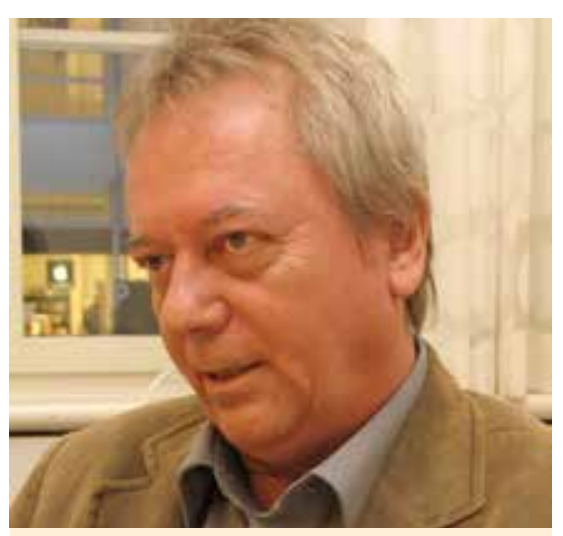

Overlæge Lars Bolvig præsenterede den specialiserede anvendelse af ultralyd-elastografi og diffusionsvægtet MR til evaluering og staging af patienter med c.recti.

Fusion af MR billeder med real-time ultralyd anvendes til optimering af UL-vejledte blokader, f.eks. lumbosacrale plexusblokader, hvilket Jennie M.C. Strid fra anæstesiologisk afdeling AUH anvendte som klinisk eksempel.

Telemedicinsk ultralyd var den beskedne titel på foredraget af de to biomedicinske studerende Søren Pallesen og Johannes Hollensberg. Det var ikke TV-konferencer, men trådløs robotultralydskanning, der blev præsenteret! Den efterfølgende pau-

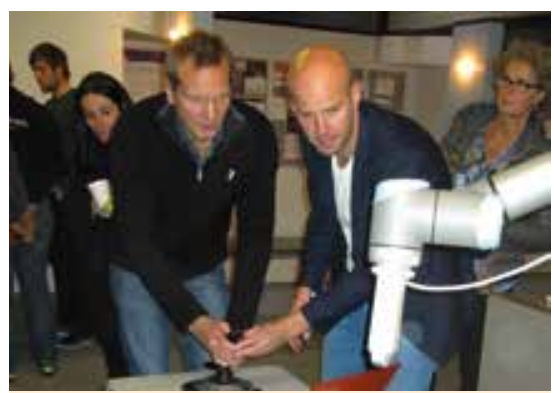

Søren Pallesen demonstrerer Telemedicinsk Robot-Ultralydskanning for DUDS kommende formand

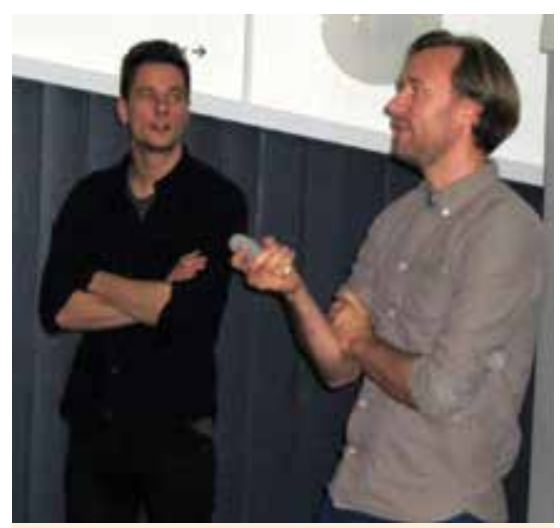

Tobias Todsen og Ebbe Lahn Bressmann se bød på andet end udemærkede forfriskninger. Her kunne deltagerne selv prøve at skanne et objekt ved hjælp af en prototyperobot som var opstillet til formålet.

Anju Pareek fra AUH radiologisk afdeling, åbnede anden del af programmet med et foredrag om neonatal lungeultralyd og formanden for DUDS, afd.læge Caroline Ewertsen, Radiologisk afd. RH, fortsatte det pædiatriske fokus, med et foredrag om anvendelsen af elastografi til vurdering af levercirrose hos børn.

Endometriose og Klinisk Ultralyd var titlen på det næstsidste foredrag holdt af Anne Gisselmann Egekvist fra AUH (Klinisk Institut/Gyn-Obs). Annes gennemgang indbefattede anvendelsen af transvaginal ultralydskanning til vurdering af recto-sigmoidal invasiv endometriose.

Sidst, men ikke mindst, kom Tobias Todsen og Ebbe Lahn Bressmanns præsentation af oplæring i klinisk ultralyd med anvendelse af simulationstræning, validerede måleredskaber til kompetencevurdering, Video/Apps og smart-phones. Begge er fra Center for klinisk uddannelse, $\mathrm{RH}$ og Dronning Ingrids Hospital Nuuk, Grønland.

Stor tak til foredragsholderne. Kæmpe fin indsats. Og tak til det interesserede og spørgelystne publikum. Flot program. Et helt igennem vellykket møde.

\section{Bjørn Skjoldbye, kommende formand} DUDS. 